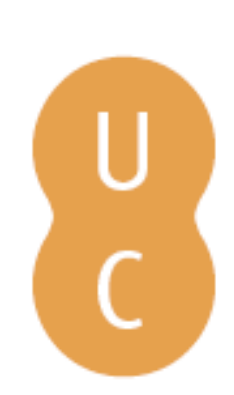

\title{
nombalina
}

\section{Super flumina: as redondilhas camonianas e outras paráfrases quinhentistas}

\author{
Autor(es): $\quad$ André, Carlos Ascenso
}

Publicado por: Imprensa da Universidade de Coimbra

URL

persistente: URI:http://hdl.handle.net/10316.2/31208

DOI: $\quad$ DOI:http://dx.doi.org/10.14195/978-989-26-0569-2_36

Accessed : $\quad$ 26-Apr-2023 14:58:04

A navegação consulta e descarregamento dos títulos inseridos nas Bibliotecas Digitais UC Digitalis, UC Pombalina e UC Impactum, pressupõem a aceitação plena e sem reservas dos Termos e Condições de Uso destas Bibliotecas Digitais, disponíveis em https://digitalis.uc.pt/pt-pt/termos.

Conforme exposto nos referidos Termos e Condições de Uso, o descarregamento de títulos de acesso restrito requer uma licença válida de autorização devendo o utilizador aceder ao(s) documento(s) a partir de um endereço de IP da instituição detentora da supramencionada licença.

Ao utilizador é apenas permitido o descarregamento para uso pessoal, pelo que o emprego do(s) título(s) descarregado(s) para outro fim, designadamente comercial, carece de autorização do respetivo autor ou editor da obra.

Na medida em que todas as obras da UC Digitalis se encontram protegidas pelo Código do Direito de Autor e Direitos Conexos e demais legislação aplicável, toda a cópia, parcial ou total, deste documento, nos casos em que é legalmente admitida, deverá conter ou fazer-se acompanhar por este aviso.

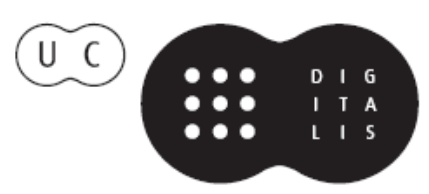




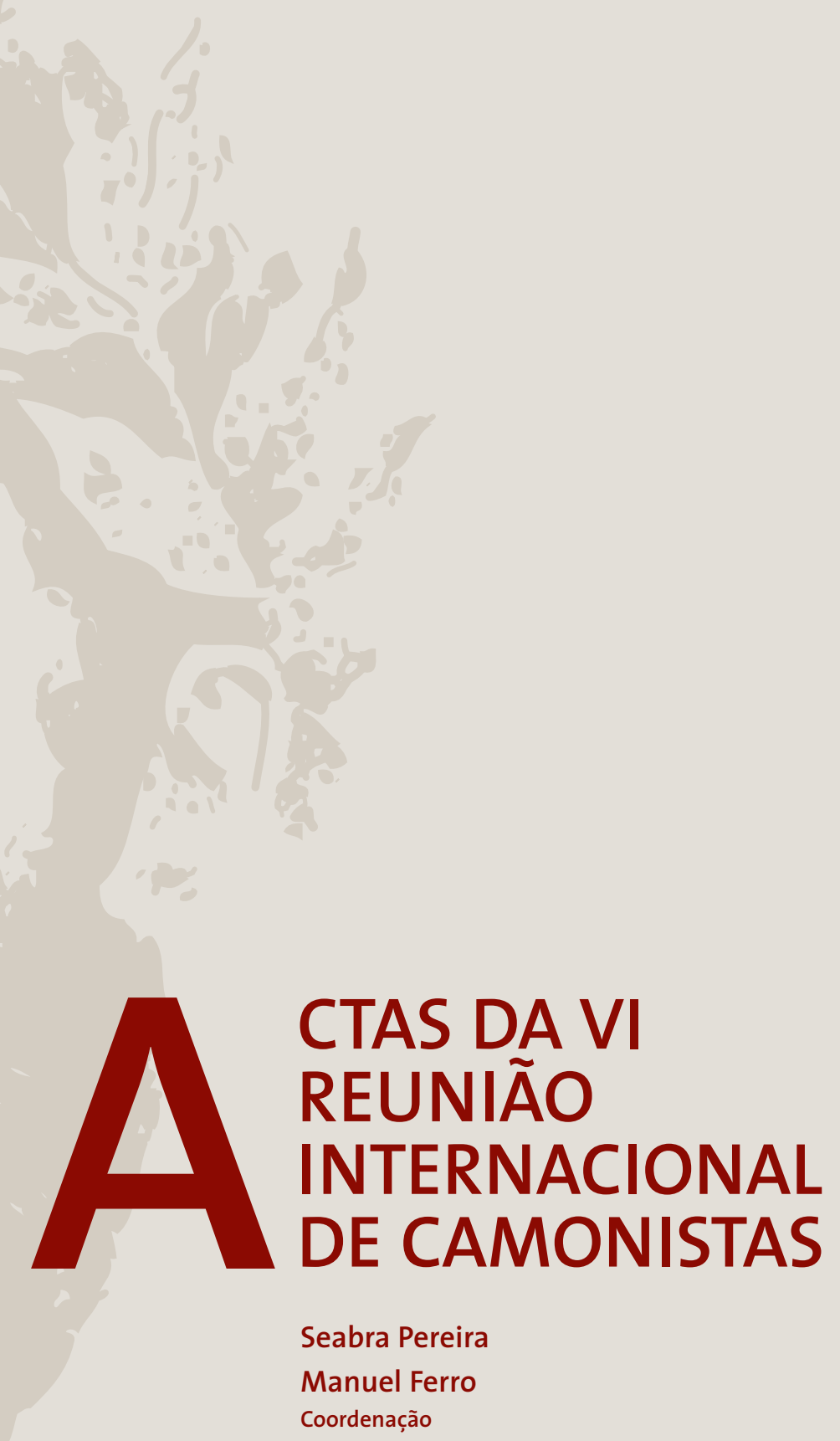




\author{
Carlos Ascenso André \\ Universidade de Coimbra
}

\title{
SUPER FLUMINA: AS REDONDILHAS CAMONIANAS E OUTRAS PARÁFRASES QUINHENTISTAS
}

O texto que foi, quase sem contestação até hoje, apelidado de «coluna vertebral da lírica camoniana», tem sido objecto de múltiplas leituras e interpretaçóes, nem sempre coincidentes.

Sem pretensóes de exaustividade, vale a pena lembrar que, entre o lúcido e ainda hoje actual estudo de António Salgado Júnior e a mais recente e arrojada hipótese interpretativa de Vasco Graça Moura, se contam muitos outros contributos para a compreensão das célebres redondilhas, como os de Jorge de Sena, Maria Vitalina Leal de Matos, Luciana Stegagno-Picchio, José Nunes Carreira, Jorge Alves Osório e tantos outros ${ }^{1}$.

De entre os temas que mais desafiaram o esforço hermenêutico dos diversos estudiosos sobressaem seguramente a dimensão religiosa do poema, o seu carácter enigmático, que parece ter fascinado particularmente Vasco Graça Moura, a íntima conexão que mantém com algumas ideias dominantes do neoplatonismo renascentista, a força dos códigos temáticos epocais, com destaque para os que configuram a lírica maneirista, e bem assim a articulação com aquele que é, sem dúvida, o seu arquitexto, o salmo Super flumina Babylonis.

Não se pretende, neste breve espaço, pôr em causa qualquer dessas leituras e interpretaçôes, cujo percurso, de resto, só em parte coincide com o que se tenciona aqui realizar, mas tâo-somente trazer algumas despretensiosas achegas às tentativas,

${ }^{1}$ A. Salgado Júnior, Camóes e sôbolos rios: ensaio de interpretação destas redondilhas, Aveiro, sep. Labor, ano X, 1936; V. G. Moura, Camóes e a divina proporção, Lisboa, Imprensa Nacional - Casa da Moeda, 2a ed., 1994; J. Sena, "Babel e Sião»: Trinta anos de Camóes, Lisboa, Ediçóes 70, 1980, pp. 113-131; M. V. L. Matos, "A suma - Comentários às redondilhas Sôbolos rios que vão»: O canto na poesia épica e lírica de Camóes, Paris, Fundação Calouste Gulbenkian - Centre Culturel Portugais, 1981, pp. 13-39; L. StegagnoPicchio, «Babel et Sion: inspiration thématique et inspiration formelle dans la glose camonienne du psaume "Super flumina Babylonis»»: L'Humanisme portugais et l'Europe, Actes du XXIe. Colloque International d'Études Humanistes, Tours, 3-13 - juillet 1978, Paris, Fundação Calouste Gulbenkian - Centre Culturel Portugais, 1984, pp. 559-598; J. N. Carreira, Camóes e o Antigo Testamento, Ponta Delgada, Universidade dos Açores, 1982; J. A. Osório, "As redondilhas sobre os rios: ensaio de leitura a partir da versão do Cancioneiro de Cristóvão Borges»: Arquivos do Centro Cultural Português 16 (1981) pp. 427-436. 
já por outros desenvolvidas, de inserção das redondilhas camonianas numa tendência manifesta da poesia quinhentista: o recurso ao Salmo 136, o canto do povo hebreu no exílio babilónico, como tema de traduções, paráfrases, comentários e não só, em latim e em vernáculo.

Essa tendência deve enquadrar-se, antes de mais, na crescente atenção que a Bíblia - e náo apenas o Livro dos Salmos - mereceu ao longo do Renascimento, aspecto que nem sempre tem sido devidamente sublinhado pelos estudiosos. Uma leitura atenta do quinto volume da monumental colecção Bible de tous les temps, intitulado precisamente Le temps des Réformes et la Bible, sob a competente direcção de dois conhecidos nomes dos estudos bíblicos, Guy Bedouelle e Bernard Roussel, revela, sem margem para dúvidas, a importância que os Livros Sagrados alcançaram entre 1500 e $1600^{2}$. A Bíblia, de facto, era centro de preocupaçóes da pedagogia humanista, a sua exegese detinha lugar de relevo em escolas e universidades, de diversificadas tendências e confissóes, constituía objecto privilegiado da actividade tipográfica recém-nascida, suscitou a atenção erudita de importantes nomes do Humanismo renascentista europeu e marcou as mais diversas manifestaçôes culturais do século XVI em múltiplas latitudes geográficas e ideológicas.

Preferiram, ao invés, os comentadores do texto camoniano que nos cumpre aqui ter presente realçar a importância do Livro dos Salmos, desde a Idade Média, na Europa, em geral, na Península Ibérica e particularmente em Portugal. Assim agiram Vasco Graça Moura, Jorge de Sena, Luciana Stegagno-Picchio e, mais vagamente embora, Maria de Lourdes Belchior ${ }^{3}$. Eu próprio, se me é permitida a pouco modesta referência, dediquei ao assunto alguma atenção. Por questóes de comodidade, seja-me lícito sintetizar, em poucas linhas, algumas das ideias essenciais que em outro lugar deixei expressas 4 .

O Saltério, a par da sua especial utilidade na oração, qualquer que fosse a tendência confessional de quem a ele recorria, oferecia aos humanistas várias outras vantagens, de não menor importância: era constituído por textos poéticos, de hermenêutica e exegese complexas e que requeriam redobrada atenção por parte da crítica textual, com inúmeras potencialidades de tratamento métrico em língua latina (e também em vernáculo) e proporcionava um quase inesgotável manancial de temas; um tal conjunto de características colocava o Livro dos Salmos ao lado das obras dos autores da Antiguidade Clássica, o que não era muito fácil no tocante a outros livros das Escrituras.

Por outro lado, a evocação de David, o lírico por excelência do Antigo Testamento, propiciava, sem riscos de suspeição heterodoxa, a concepção neoplatónica da inspiração poética; o rei e poeta substituía Orfeu, sem com isso ferir a ortodoxia 5 . Como disse

${ }^{2}$ G. Bedouelle et B. Roussel (eds.), Le temps des Réformes et la Bible, Paris, Beauchesne, 1990.

${ }^{3}$ M. L. Belchior, Os homens e os livros: séculos XVI e XVII, Lisboa, Editorial Verbo, 1971.

${ }^{4}$ C. A. André, "Tempo de convergências: a terra, lugar de exílio": Mal de ausência: o canto do exílio na lírica do humanismo português, Coimbra, Minerva, 1992, pp. 275-355. Vd., em especial, pp. 288-355, o sub-tema «Super flumina Babylonis, um caso modelar». Este texto, que constitui ponto de partida para a maior parte das reflexôes aqui produzidas, passará a ser citado apenas por Mal de ausência.

${ }^{5} \mathrm{Vd}$. M. Jeanneret, Poésie et tradition biblique au XVIe. siècle: recherches stylistiques sur les paraphrases des "Psaumes», de Marot à Malherbe, Paris, José Corti, 1969, p. 200 e pp. 309-316. 
Jorge de Sena, «o Psaltério, lendariamente obra do Rei que, autor e actor, era o símbolo do escolbido de Deus e do poeta enquanto tal, desempenharia um decisivo papel, quer como fonte directa, quer como indirecto arsenal de similes, metáforas, imagens, para a celebração de uma comunicação poética entre o homem e Deus» ${ }^{6}$.

Finalmente, já na fase crepuscular do Renascimento, o canto bíblico adequa-se igualmente ao gosto pelas imagens excessivas e pelo exagero, táo apreciadas pela estética do Maneirismo 7 .

Por isso se sucederam, ao longo do século XVI, as edições dos Salmos, no todo ou em parte, em latim ou em vernáculo, nos vários países da Europa; tantas que a sua inventariação deu já origem a trabalhos de grande erudição por parte de diversos investigadores, assentes em aturadas buscas por bibliotecas e arquivos ${ }^{8}$.

Seria ocioso repetir aqui a enumeração já feita por esses autores. Mas, pela sua especial importância no contexto do Humanismo renascentista, do qual Camóes, como é sabido, não pode dissociar-se, não é despiciendo referir em pormenor as traduçôes latinas e paráfrases de humanistas europeus de renome, quase todos contemporâneos de Camóes e cujos textos, em alguns casos, o nosso poeta pode muito bem ter conhecido.

Uma advertência, em todo o caso, se impóe: náo se depreenda deste elenco e da análise que lhe é subsequente qualquer intençấo de ler as redondilhas camonianas à luz da tradicional crítica de fontes, tanto mais que náo pode assegurar-se que o poeta português conhecesse tais textos, alguns dos quais, de resto, lhe são posteriores; pretende-se, antes, estabelecer um conjunto de relaçôes intertextuais que, posto que não deliberadamente assumidas, náo podem deixar de constituir um elemento de considerável importância na indagação do texto de Camóes.

Se estabelecermos, por simples comodidade de procedimento, que o poeta poderá ter composto o seu poema após o regresso da Índia, ser-lhe-ão anteriores os seguintes:

- O Quincuplex Psalterium, de Lefévre d'Étaples, publicado em Paris, em 1513.

- Uma espécie de antologia com versóes de diversos autores, intitulada Psalmi omnium selectissimi, onde figuram traduções em verso latino por Melanchton e Hesse, entre outros, e onde o salmo 136 é da responsabilidade de Nicolau Hermann (1532).

- O Psalterium Davidis, de Hélio Heoban Hesse, cuja primeira edição é de $1539^{9}$.

- As paráfrases de Salmon Macrin ou Jean Salmon Maigret, publicadas em 1537 e reeditadas em 1538 .

- O Psalterium de Johann Spangenberg, publicado em Frankfurt, em 1544.

${ }^{6}$ J. Sena, op. cit., p. 121.

${ }^{7}$ M. Jeanneret, op. cit., p. 444.

${ }^{8}$ Três títulos justificam aqui menção especial: J. A. Fabrício, Votum Dauidicum, Hamburgo, 1729, pp. 71-116; H. Vaganay, "Les traductions du Psautier en vers latin au XVI ${ }^{\text {. }}$ siècle»: Compte rendu du quatrième Congrès International des Catholiques (Fribourg, du 16 au 20 août 1897) — sixième section - sciences philologiques, Fribourg (Suisse), Imp. et Lib. de l'Oeuvre de Saint-Paul, 1898, pp. 162-182; J. A. Gaertner, "Latin verse translations of the Psalms: 1500-1620»: The Harvard Thelogical Review 49.4 (1956) 271-305.

9 Os textos de Hélio Hesse, Marco Antonio Flaminio, Jean Salmon Maigret e ainda George Buchanan, todos eles citados a seguir, foram reunidos em edição de Henri Estienne, com o título Davidis Psalmi aliquot, saída a lume em Paris, em 1556. Foi essa a versão seguida para este trabalho, excepto no caso de Hesse, em que se utilizou a edição de Paris, 1547. 
- A Paraphrasis in triginta Psalmos, de Marco Antonio Flaminio, saída a lume com os Carminum libri duo, em 1546.

- Os Psalmi Davidis centum, in carmen conversi, de J. Latomus, a que se juntam, na mesma edição, doze versóes de Pierre Nanninck (entre as quais a do salmo 136), publicados em Lovaina, em 1558.

- De Adam Siber, a edição de Basileia de Poematum sacrorum pars prima, a que acrescem os Psalterii seu carminum Davidicorum libri V, em 1562.

- A Bíblia, em tradução latina de Sébastien Châteillon, publicada em 1556.

Relativamente mais tardios, mas com possibilidade ainda de serem contemporâneos das redondilhas, são:

- Os Davidis regis ac prophetae aliorumque sacrorum vatum Psalmi, de Bento Arias Montano, saídos a lume em Antuérpia, em 1574. Apesar da data, mencionam-se aqui, por atenção a Jorge de Sena, que sugere a hipótese de Camôes conhecer esta versão ${ }^{10}$.

Se prolongarmos a enumeração até final do século (e, repita-se, ela não é exaustiva, limita-se apenas a alguns dos mais conhecidos nomes do Humanismo europeu e refere somente os casos em que a edição abrange o salmo 136), encontramos:

- A edição do francês Jean Dorat - Psalmi Davidis ex hebraica veritate latinis versibus expressi, publicada por Mattheo, em 1575, em Paris.

- Do calvinista Théodore de Bèze, ou Beza, os Psalmorum Davidis et aliorum prophetarum libri quinque, de Genebra, 1579.

- No mesmo ano de 1579, o Psalterium Davidis integrum, por Frederico Widebram, em edição de Estrasburgo.

- Psalmodia, de Bartolomeo Botta, Pavia, 1580.

- Os Eximii prophetarum antistitis regia Davidis oracula, de François de Bonade, saídos em Paris, em 1581.

- No mesmo ano de 1581, o Enchiridion Psalmorum Davidis regii prophetae ex Hebraica veritate, por François Mouret, em Basileia.

- Davidis regii prophetae Psalterium, de Maurício, o Sábio, Landgrave de Hessencassel, 1587.

- Os Psalmi Davidis centum quinquaginta paraphrastice translati in versus heroicos, por Guy de Coquille, editados em Nevers, em 1592.

- Psalmorum Davidis LXII [...] paraphrasis poetica, por Gregorio Bersman, em 1596.

Este inquestionável fascínio pelo Saltério atingiu igualmente Portugal. Importa referir:

- George Buchanan que, apesar de não ser português, terá composto no nosso país a sua Paraphrasis Psalmorum Davidis poetica, várias vezes editada, uma das quais, como atrás se disse, com os textos de Hélio Hesse, Marco Antonio Flaminio e Jean Salmon Maigret, por Henri Estienne, em Paris, em 1556.

- O humanista Aquiles Estaço, cujas paráfrases de alguns salmos, entre os quais o 136, só há pouco tempo veio a ser publicada ${ }^{11}$.

${ }^{10}$ J. Sena, op. cit., p. 124.

${ }^{11}$ Integradas no artigo de M. T. Bartolli, "A proposito di Aquilles Estaço e dei Carmina del codice Vallicelliano B 106»: Annali dell'Istituto Universitario Orientale - Sezione Romanza 17 (1975) 293-362. 
- O Liber Psalmorum cum poetica interpretatione, do Padre Luís da Cruz, vindo a lume em 1597, em Ingolstadt.

No que toca especificamente ao Salmo 136, este número alarga-se razoavelmente, com diversos outros nomes, além do de Camóes:

- Jorge da Silva, no final do Tratado da creaçáo do mundo e dos mysterios de nossa redempção, de Lisboa, 1552, publica as «Endechas dos Psalmos e dos Canticos», um poema com indubitável inspiração no texto bíblico, escrito em castelhano e parcialmente idêntico a um texto que figura como anónimo no Cancioneiro de Évora.

- Uma longa paráfrase de Jorge de Montemor, também em castelhano, quase tão longa como a de Camóes, saíu a lume em Antuérpia, em 1558, no Segundo cancionero espiritual.

- Em 1579, Lopo Serrão publica, com o seu De senectute, uma Deploratio populi Israelitici prope flumina Babylonis, primeiro em longa paráfrase e, depois, em duas versôes abreviadas ${ }^{12}$.

A estas versôes impressas convém juntar algumas outras, que permaneceram manuscritas e que pela primeira vez editei há poucos anos ${ }^{13}$ :

- Um conjunto de quintilhas intituladas Ho psalmo Super flumina Babylonis em troua sem se mudar nada da sentença a noso proposito. De datação difícil, este poema, que publiquei após dele ter tido notícia pela Professora Luciana Stegagno-Picchio ${ }^{14}$, faz parte de um manuscrito do núcleo da Manizola, da biblioteca de Évora ${ }^{15}$. Pelo conjunto de documentos do códice, presumo que possa situar-se no terceiro quartel do século XVI; se assim for, será contemporâneo de Camóes, com possibilidades de ser anterior às redondilhas, o que assume particular importância se atendermos às profundas relaçóes intertextuais existentes entre ambos, como a seguir se verá.

- Um exercício poético em latim, em três versôes metricamente diferenciadas, provavelmente da autoria do jesuíta Álvaro Lobo, que pode, com alguma segurança, datar-se do terceiro quartel do século XVI, cujo manuscrito se conserva em Évora ${ }^{16}$.

- Igualmente em jeito de exercício, também em latim, com dois modelos métricos, uma Cantiga de Hierusalem, que se conserva na biblioteca da Ajuda ${ }^{17}$.

- Mais tardia, seguramente, talvez do século XVII, é uma paráfrase em português, em oitavas heróicas, cujo manuscrito se encontra na mesma biblioteca da Ajuda ${ }^{18}$.

Finalmente, há que mencionar dois textos em prosa: a larga utilização do salmo 136 na Imagem da vida cristã, de Frei Heitor Pinto, cuja relação com o texto camoniano foi amplamente estudada, nomeadamente por Eduardo Lourenço e por Vasco Graça

\footnotetext{
12 Seguiu-se a edição crítica de S. T. Pinho, Lopo Serrão e o seu poema Da velhice, Coimbra, Centro de Estudos Clássicos e Humanísticos - I.N.I.C., 1987.

${ }^{13}$ Mal de ausência, apêndice ao cap. V da II parte, pp. 340-355. Todos os textos citados a seguir estão aí publicados na íntegra.

${ }^{14}$ L. Stegagno-Picchio, op. cit., p. 575.

15 Bib. Pública e Arquivo Distrital de Évora, ms. 348, Manizola.

16 Ibidem, ms. CXIV/1-39.

${ }^{17}$ Biblioteca da Ajuda, ms. 49-III-51, fl. 11-11vo.

18 Ibidem, ms. 49.I.7.
} 
Moura ${ }^{19}$; e as Annotationes in Davidicos Psalmos, de Frei Bartolomeu dos Mártires, escritas em 1561, mas somente publicadas em $1735^{20}$.

Luís de Camôes, homem de muita cultura e grande erudição, atento, além do mais, ao seu tempo, respirou seguramente esta atmosfera cultural e não podia ficar imune às suas influências. Desvendar se conheceu directamente cada um destes textos seria, por certo, interessante, mas afigura-se tarefa quase impossível; é inegável, todavia, que formou a sua personalidade literária dentro deste ambiente em que era notório o fascínio pelo Saltério e, dentro dele, pelo Salmo 136; logo, seria difícil imaginar que as várias linhas de força que orientaram a recorrente utilização do texto bíblico no seu tempo pudessem passar-lhe despercebidas.

São essas relações que se pretendem aqui sumariamente enunciar, com destaque para aquelas que se verificam entre Camóes e textos produzidos em território peninsular, especialmente em território português.

A dependência das redondilhas Sobre os rios que vão em relação ao Salmo 136 foi pormenorizadamente estabelecida por José Nunes Carreira, em análise assente em profundo conhecimento da Sagrada Escritura, e também por Vasco Graça Moura. Este define como pontos de contacto entre o salmo bíblico e Sobre os rios treze quintilhas: $1,11,25,29,37,39,40,57,60,63,64,66,67^{21}$. Sem pôr em causa a verdade desta afirmação, deve, em todo o caso, referir-se que nem a relação entre os versículos bíblicos e tais quintilhas é literal nem estas se limitam ao conteúdo daqueles; como deve igualmente sublinhar-se que a enumeração de Vasco Graça Moura omite uma quintilha cujo débito em relação ao salmo não é menos evidente (quintilha 20):

"Órgãos e flauta deixava

despojo meu tão querido

no salgueiro que ali estava."

Deixemos, pois, a relação com o texto bíblico e olhemos as paráfrases, interpretaçôes, comentários e traduçôes contemporâneas do poeta português. Por motivos óbvios, nos casos em que a presença do salmo é manifesta, não se menciona qualquer outro texto.

Assim:

A força do pranto, comparável a uma torrente que engrossa as próprias águas do rio (quintilha 2), é comum a vários autores; surge, nomeadamente, em Buchanan, Aquiles Estaço e Jorge de Montemor. E, na mesma quintilha, a comparação entre o presente e o passado, consubstanciados, respectivamente, em Babilónia e Sião, regista-se em Jorge da Silva. Buchanan acrescenta aos motivos de dor a species miseranda Sionis.

O conjunto das quintilhas 3 e 5 está intimamente relacionado com o manuscrito da Manizola. Repare-se:

${ }^{19}$ E. Lourenço, "Camóes e Frei Heitor Pinto": Arquivos do Centro Cultural Português 16 (1981) 361370; V. G. Moura, op. cit., pp. 105-120.

${ }^{20}$ Edição recente: Frei Bartolomeu Dos Mártires, Comentário aos Salmos (edição bilingue), introdução, traduçấo e anotaçôes de M. I. Alves, Fátima, 1991.

${ }^{21}$ Op. cit., pp. 153-155. 
"Lembra nos as abastanças

e antiguo contentamento;

mas, o tristes de lembranças,

que nam prestais nas mudãças,

senam pera mais tormento.

Lembra nos quam descansados

uiuiamos, sem se cuidar

quisto auia de pasar;

mas em fim em os bóos fados

os maos se ham dadiuinhar."

Compare-se com:

"Ali, lembranças contentes

n'alma se representaram,

e minhas cousas ausentes

se fizeram táo presentes

como se nunca passaram.

$[\ldots \ldots \ldots \ldots]$

E vi que todos os danos

se causavam das mudanças

e as mudanças dos anos;

onde vi quantos enganos

faz o tempo às esperanças."

Além disso, o rosto banhado em água é, em Buchanan, o colo (sinus), sobre o qual tomba o caudal. E o jogo verbal entre mágoa e água surge também no texto da Manizola:

"Chorando noso desuio, lagrimas em nosas magoas

nos correm fio em fio;

andamos de rio em rio,

que terra he de muitas aguoas."

A mesma quintilha 5 , juntamente com a 6 , corresponde, do ponto de vista das ideias expressas, posto que a semelhança verbal possa não ser táo intensa, às quintilhas 7 e 15-16 do manuscrito da Manizola:

"Que, a quem o bem he mudado, alembra [r] the que foi ja faz lhe seu mal ser dobrado; e quanto foi moor estado, tanto mor pena lhe daa. 
$[\ldots . .$.

E nosos olhos ueram

nosos proprios bẽ es seus serẽ;

que em fim os bẽ es q̃ dũ us sam

pasam dũ a ha outra mão

nos tempos que soçederem.

Asy ho uemos aguora,

quisto he proprio do bem:

dũ s se uam a outros uem;

e o que bem teue algũ a ora

outras oras males tem."

Como poderá, ainda no mesmo passo, aproximar-se a quintilha 7 de Camóes da quintilha 11 do texto eborense, já citada:

"mas em fim em os bóos fados

os maos se ham dadiuinhar."

O arrependimento, a que Camóes alude logo depois (quintilha 8) é comum a Théodore de Bèze, que falava da consciência de culpa dos Hebreus, em resultado dos excessos a que se haviam entregado.

E a palavra contentamento, a este propósito, é comum a Camôes e ao manuscrito de Évora.

Quanto à quintilha 9, detém íntimas semelhanças com muitos autores, pois é usual a comparaçáo das lágrimas à corrente de um rio. Buchanan, por exemplo, falava de imber liquidae aquae. Mas a maior semelhança, atendendo ao jogo verbal entre mágoas e ágoas, é, uma vez mais, com o texto da Manizola já acima citado. Além de que a confusão de Babel é herdada de Santo Agostinho.

Deixemos a quintilha 10 , sem paralelo nos textos vistos, tal como a 11 , directamente dependente do salmo bíblico. Refira-se apenas, quanto à controvérsia que se tem gerado, por vezes, na crítica, a propósito da identificaçáo dos instrumentos que se abandonam dependurados nos salgueiros, que nem todos os autores são fiéis aos organa do salmo; encontramos também a alusão à lira (Buchanan), lira e cítara (Aquiles Estaço), lyra, barbyton e cythara (Botta); até mesmo a flauta náo é exclusiva de Camóes, pois se encontra no texto de Hermann.

O canto sobre o poder do canto, isto é, a celebração da dimensão órfica da poesia, tema das quintilhas 13 a 17, só ocorre em Camóes, no que a textos desta natureza diz respeito. Constitui, todavia, um tema de grande profusão ao longo do Renascimento, e o próprio Luís da Camóes faz dele larga utilização em outros lugares, o que diminui, de alguma forma, a sua importância nestas redondilhas.

Corrente é também o tema da mudança, a encerrar a quintilha 17 e que se desenvolve nas 18 e 19, além de atravessar quase todo o texto; ele é, de igual modo, uma das marcas mais salientes do texto da Manizola. 
Não surpreende, portanto, que a conclusão do conjunto volte a aproximar ambas as versóes. Camóes rematava:

"Fraqueza da humana sorte

que quando da vida passa

está receitando a morte!"

Com o que o manuscrito revela semelhanças evidentes:

De tudo nos despojaram

"e nos corpos tais ficamos.

Os que quiseram, mataram;

e nos, a quem perdoaram,

pior que os mortos estamos.

Em dura prisam catiuos

com catiueiro tão forte,

que se pode chamar morte;

temos pareçer de uiuos,

mas de mortos he a sorte."

Além disso, a espessura onde fica o canto camoniano não difere muito do luguar deserto e hermo da versão manuscrita de Évora.

Já a sequência da quintilha 21 não tem paralelo, ao passo que o final da 22 surpreende, na medida em que parece ser uma resposta a Jorge de Montemor. Diz, de facto, o poeta das redondilhas que

"nunca em mim puderam tanto

que, posto que deixe o canto,

a causa dele deixasse."

Contra a afirmação de Montemor, que sustentava

"No las flautas y organos dexamos,

mas las laegres causas que tuuimos

delos hymnos y cantos que cantamos."

A quintilha 24 é outro ponto de contacto com o salmo, acrescido de elementos de pormenor que podem encontrar-se também em Jorge de Montemor (despojos de guerra) ou em Bèze (as cítaras à vista dos Babilónios).

$\mathrm{E}$, se a quintilha 25 corresponde ao salmo, a pergunta retórica que se segue ("que foi daquele cantar / das gentes tão celebrado?») é comum à larga maioria das paráfrases quinhentistas.

Seguem-se duas quintilhas, onde se celebra o canto e suas virtudes; são tema corrente em Camóes, que o herda da poesia clássica, nomeadamente de Horácio e Ovídio. 
A nova intersecção com o salmo ocorre logo a seguir, na quintilha 29; aí, contudo, a oposiçáo doce canto em terra alheia, não se registava no texto bíblico; coincide, todavia, com o manuscrito de Évora que contestava o

"Cantarmos em terra alhea doçes himnos ao Sñor.”

Logo depois (quintilha 30), convergem elementos comuns a diversas outras versóes: a impossibilidade de cantar em tempo de pranto é mencionada por Buchanan que dizia os laeta carmina impossíveis in mediis malis; Aquiles Estaço - e, com ele, muitos outros - referia que o inimigo havia reclamado in lacrimis laetos modos; e o manuscrito da Manizola replica (quintilha 29):

"Como quereis que cantemos?

Se nos mãdais q̃ choremos, nosos olhos ja ho fazem."

Também ali se verifica a oposição camoniana entre cansar e chorar, logo no começo do texto e, depois, a propósito da exigência babilónica:

"Mas anda tão ocupado quem tem males e fadiguas, quali soo tras ho cuidado; e a homẽ afadiguado não lhe falem em cãtiguas."

Vale a pena cotejar todo este leque de referências com as quintilhas camonianas:
"Eu, qu'estas cousas senti
n’alma, de mágoas tão cheias,
como dirá, respondi,
quem táo alheio está de si
doce canto em terra alheia?
- Como poderá cantar
quem em choro banha o peito?
Porque se quem trabalhar
canta por menos cansar,
em só descansos enjeito.”

A impossibilidade de entoar em Babilónia os cantos de Siấo, objecto da quintilha 31, é comum a Buchanan e, embora de modo menos evidente, a outros autores.

Já a relação entre o canto e a tristeza, bem como a ambiguidade do uso da palavra pena são uma característica específica de Camóes, não exclusiva, de resto, destas redondilhas, pois constituem, como se sabe, um dos temas fortes de toda a sua lírica. 
Passemos à quintilha 37. Aí, o contacto com o texto bíblico, a que se refere Graça Moura, é de simples pormenor, pois o que mais destaque merece continua a ser a ambiguidade da pena, a qual se deseja "seja dada / a perpétuo esquecimento», como condenação pelo eventual esquecimento da terrra pátria. Neste caso, a meu ver, Camóes retoma um topos da literatura do exílio, patente, por exemplo, em Ovídio: o receio de que a maior condenação de todas será o esquecimento do desterrado e bem assim da pena que lhe foi infligida; por isso, o canto enviado para a pátria tem como finalidade avivar na lembrança dos concidadãos a desgraça em que é forçado a viver ${ }^{22}$.

Outro castigo, a perda da voz, que o salmo não registava, figurava em Buchanan: os mihi destituat uox. A despeito da semelhança com o salmo, não pode, além disso, passar despercebida a coincidência entre Camóes e o manuscrito da Manizola:

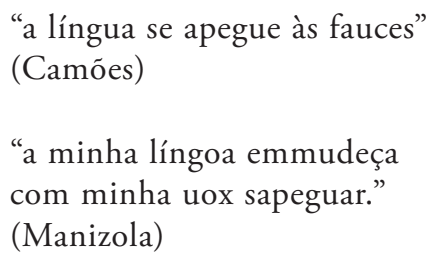

A partir daqui, tem lugar uma das manifestaçóes do neoplatonismo renascentista, aspecto em que o nosso poeta é único, pelo menos nos exemplos que me foi dado ver; como se sabe, a importância do neoplatonismo em Camóes tem sido fonte de amplo debate por parte dos estudiosos, e não é aqui o momento para versar essa tão uexata questio. Permita-se-me, no entanto, sublinhar dois ou três aspectos:

a)Também Jorge da Silva tem um desenvolvimento semelhante, posto que mais ligeiro, por certo colhido nos comentários de Santo Agostinho, o qual já fazia uma leitura deste tipo do salmo 136.

b)A evocação da "terra onde naceu / a carne» é comum ao manuscrito eborense, que evoca "a terra onde fomos nacidos».

c)Algumas das afirmaçôes camonianas não pressupóem necessariamente o conhecimento directo dos diálogos platónicos para que remetem; Camóes pode muito bem tê-las colhido na leitura das Tusculanas, a obra ciceroniana que o Renascimento tomou quase como um "guia espiritual" 23. Dois exemplos apenas, entre vários: a alusão à memória e reminiscência encontra-se no capítulo 57 do diálogo de Cícero, que lembra o Ménon, de Platão; aí se cita a «memoria» como uma das faculdades da alma e se diz que o conhecimento mais não é do que «reminiscendo recognoscere», isto é, "reconhecer através da reminiscência". E a menção de que a "alma á tábua rasa» é, por outras palavras, o cerne do capítulo 61: nele, Cícero contesta a concepção da alma como um «uas», ou seja, um "vaso" onde estaria armazenada a lembrança, e pretende, antes, que a alma é como uma das tabuinhas de cera que serviam para

22 Não me ocuparei aqui deste assunto, já tratado em outro lugar (Mal de ausência, p. 315).

23 A aproximação entre as redondilhas e as Tusculanae disputationes, de Cícero, é sugerida por A. C. Ramalho, "Camóes e o Humanismo renascentista": Camóes no seu tempo e no nosso, Coimbra, Almedina, 1992 , p. 128. 
gravar a escrita: "Imprimi quasi ceram animum putamus, et esse memoriam signatarum rerum in mente uestigia».

d) Em meio do conjunto de quintilhas onde são visíveis as marcas de neoplatonismo, ocorrem outras semelhanças com os autores que têm vindo a ser citados: a oposição "cantares de amor profano" e "versos de amor divino" (quintilha 47) é comum a Aquiles Estaço que recusava que nos «Domini sanctos posse referre modos» e a George Buchanan, o qual questionava textualmente:

"Siccine diuinos Babylon irrideat hymnos?

Audiat et sanctos terra profana modos?"

A semelhança com o poeta escocês perdura, aliás, na quintilha seguinte, a 48 .

Deixemos, pois, de lado a controvérsia sobre o neoplatonismo camoniano, para passarmos a um outro passo, onde a originalidade do nosso poeta é, uma vez mais, aparente: o retomar do canto, nas quintilhas 51 e 54, com a opção definitiva pelo abandono da flauta, a fim de empunhar a lira. É verdade que a oposiçáo entre os dois instrumentos se não verifica em outros autores; o mesmo se não dirá, porém, do projecto de reassumir o canto: também em Jorge de Montemor o canto é recuperado, já na pátria verdadeira, após a vingança, e, com ele, os organos antes abandonados:

"Entonce el Criador, hecho criatura, nos mandara los organos; tomemos que en los salzos colgamos, de amargura.

La gracia que perdimos, entendemos por estes instrumentos, que colgamos; la qual por medio del, cobrar podemos.

Y los cantares dulces que dexamos de cantar, en la terra del pecado, en la de gracia entonce renouamos."

A este propósito, Frei Bartolomeu dos Mártires dirá, no seu comentário, que o abandono do canto é transitório e que, quando os salgueiros voltassem a ter ouvidos propícios, poderia ele retomar-se.

Quanto à oposição entre a Babilónia infernal e a pátria verdadeira, no céu (quintilha 52), é comum a todos os comentários, desde Santo Agostinho, como se viu; evidente é, além disso, a semelhança verbal entre o último verso dessa quintilha - Pátria minha natural - e a segunda quintilha do manuscrito eborense que classificava Jerusalém como nosa patria natural.

Curiosa é também a coincidência vocabular entre a quintilha 54 e o verso 43 de Jorge de Montemor, posto que em momentos bem diferentes de cada um dos poemas: dizia este, ainda no começo, que estava perdida «la vision de paz»; Camóes, reassumida a lira, exorta: «cante-se a visáo de paz».

Sem paralelo com qualquer dos autores analisados são as quintilhas 55 e 56 , que antecedem a nova intersecção com o salmo, na 57 . Aqui, no entanto, além da relação 
com o texto bíblico, repete-se uma outra coincidência evidente com as quintilhas anónimas da Biblioteca de Évora, onde se dizia:

"Lembrate de castiguares

os filhos de Edom, Sñor."

A semelhança com «lembrai-vos de castigar / os ruins filhos de Edom» é manifesta.

O canto da vingança, nas quintilhas 57 a 67, mantém íntimas relaçôes com o Salmo 136 e também com a paráfrase de Buchanan; exceptuam-se as quintilhas 59, 62 e 65, cujo conteúdo não tem correspondência em qualquer uma das diversas paráfrases mencionadas. Esta originalidade verifica-se igualmente nas últimas quintilhas, de 68 a 72 .

Já o final do poema, o repouso:

"Ditoso quem se partir para ti, terra excelente, tão justo e tão penitente que, depois de a ti subir, lá descanse eternamente."

corresponde à conclusão de Jorge de Montemor:

"De Dios verna el esfuerço, y el consuelo, sera Dios su caudillo, enesta guerra, y el trabajo y fatiga, aca en la tierra.

Sera gloria y descanso, alla en el cielo."

Se olharmos globalmente o vasto feixe de relaçôes intertextuais que acabam de descrever-se e sem prejuízo de este ponto de vista carecer de maior confirmação, fundamentada em rigorosa análise de pormenor, quase palavra por palavra, parece legítimo inferir, desde logo, algumas conclusôes.

As redondilhas Sobre os rios que vão, como tantos estudiosos já sublinharam, longe de constituírem um acto poético isolado, integram um amplo conjunto de textos da poesia renascentista marcados por aquilo que pode considerar-se o fascínio pelo salmo 136, Super flumina Babylonis. É desse salmo que todos os textos que de um tal imenso corpus fazem parte são devedores. Mas todos mantêm entre si fortes relaçóes intertextuais, para além das que resultam inevitavelmente da dependência em relação ao texto bíblico que está na origem de todos eles.

As redondilhas camonianas não constituem excepção; mantêm múltiplas ligações intertextuais a esse corpus, mais do que à primeira vista parece e mais também do que costuma ser mencionado pelos diversos comentadores.

De entre os vários textos com os quais é mais intensa a semelhança do poema de Camões, dois, em especial, sobressaem:

- A paráfrase de George Buchanan, o que não deixa de ser surpreendente, se atendermos ao facto de que se trata de um poeta perseguido pela Inquisição portuguesa, reformista confesso e cuja paráfrase, talvez por isso mesmo, influenciou fortemente as que foram compostas por outros humanistas protestantes. 
- Uma canção anónima, que faz parte de um manuscrito da Biblioteca de Évora, semelhante ao texto camoniano na própria forma, pois está composto em quintilhas.

- A presença, nas redondilhas de Camões, desta anónima paráfrase, se é que paráfrase pode chamar-se, tal é o afastamento do salmo, não se limita, entretanto, ao plano formal: muitos dos temas que vão sendo desenvolvidos ao longo de Sobre os rios que vão encontram-se igualmente ali, e a coincidência verbal em determinados passos nucleares é surpreendente.

- Assim, após detida comparação com as múltiplas paráfrases contemporâneas, em latim, em português e em castelhano, um estudo atento que prescinda de diferenças de pormenor relativamente irrelevantes concluirá por um número diminuto de quintilhas de conteúdo exclusivamente camoniano. São elas:

Primeiro, as quintilhas 13 a 16, onde se descrevem as consequências do abandono do canto. Trata-se, como atrás se disse, de versos onde transparece inequivocamente uma concepção órfica da poesia, a qual, até mesmo na obra de Camóes, se náo limita a este poema.

Depois, as quintilhas 27 e 28, onde se celebra o canto e suas virtudes, de um modo que não repugnaria a qualquer poeta clássico, nomeadamente Horácio ou Ovídio.

A seguir, as quintilhas 35 e 36; centradas na ambiguidade da palavra "pena» e, uma vez mais, na consequência da perda do canto, não constituem, também elas, um exclusivo das redondilhas.

Finalmente, o largo número de quintilhas de marca inequivocamente neoplatónica, desde a 43 até à 50 e também da 69 à 72. Doze, portanto. Aqui reside, a meu ver, o núcleo essencial das redondilhas Sobre os rios, na medida em que são aquelas onde as relações intertextuais com o arquitexto e com os textos dele derivados são mais ténues, senão inexistentes. No total das setenta e cinco quintilhas, é uma percentagem escassa e, ainda assim, marcada por S. Agostinho e por Cícero. Mesmo aí, além disso, Camóes não logra escapar à influência de um outro tipo de temática que com o salmo 136 mantém indesmentíveis afinidades: a da literatura do exílio, cujos topoi a Antiguidade definiu com Cícero, Ovídio e Séneca e que o Renascimento veio a cultivar largamente.

Seja-me permitido sublinhar, uma vez mais, o que já no início tive oportunidade de dizer: a abordagem aqui realizada não pretende inserir-se na tradicional crítica de fontes; ou seja, não se deseja, com tudo quanto acaba de dizer-se, sustentar a dependência de Luís de Camóes em relação aos textos que vieram sendo sucessivamente mencionados. Parece, no entanto, inquestionável a existência de um vasto feixe de relaçóes intertextuais $\mathrm{e}$, portanto, que o nosso poeta, na concepção das suas redondilhas, não foi imune às influências da atmosfera cultural em que vivia.

É certo que este conjunto de conclusôes não pôe em causa o carácter nuclear das redondilhas Sobre os rios que vão no contexto da produção lírica camoniana; parece, no entanto, evidente que uma parte dos atributos em que costuma assentar o encomiástico juízo de valor de muitos estudiosos náo resiste à análise comparativa, a que acima se procedeu, com outros textos contemporâneos. Um tal cotejo revela, sem margem para dúvidas, que as redondilhas ocupam, não um lugar único na lírica portuguesa quinhentista, mas sim um lugar cimeiro no âmbito de um vasto leque de poemas que obedecem a uma mesma matriz temática e, náo raro, formal e que entre si se interligam em imensa teia de afinidades, inclusivamente vocabulares. 
Sai, pois, consideravelmente atenuada a originalidade do poema. Poderá daí resultar a necessidade de o olharmos a uma luz diferente e segundo novos critérios; não creio, porém, que isso diminua, de alguma forma, o rico manancial que a crítica tem encontrado em Sobre os rios que vão, embora esse seja assunto que a escassez de tempo não permite aqui debater. Os códigos a que obedece a criação literária no século XVI são bem diferentes dos que hoje a regem; a imitatio e a aemulatio detêm neles lugar primordial. Se assim náo fosse, muitos dos monumentos literários do Renascimento perderiam o seu valor, entre eles, quem sabe, os próprios Lusíadas, que tanto admiramos e respeitamos; mas o respeito e admiração que legitimamente lhes votamos não ficam a dever-se, por certo, à sua originalidade ou à exclusividade do seu conteúdo. 